\title{
Reflections on Constitutionalizing Women's Equality
}

\author{
Mary Anne Case $\uparrow$
}

In commenting on Kathleen Sullivan's Brennan Lecture, Constitutionalizing Women's Equality, I am, in a sense, continuing a conversation begun nearly fifteen years ago, in a seminar on Groups, Inequality, and the Constitution, which was the first course Sullivan taught as a professor and one of the last I took as a student at the Harvard Law School. The first item worthy of comment in this Brennan Center Jorde Symposium is how little has changed in the intervening years with respect to the constitutional law concerning the group whose equality is here at issue: women. ${ }^{1}$ Indeed, so little has changed that Sullivan could well have delivered a virtually identical lecture fifteen years ago. Perhaps because the core of this law has been so firmly established for so many years after having been so close to nonexistent for so many preceding centuries, Sullivan's lecture is largely backward looking, with little in the way of predictions or prescriptions for the future. In this response, I offer my own version of the history and then apply soine of Sullivan's analytic dichotomies in a somewhat more forward-looking way, to aspects of the constitutionalization of women's equality not yet fully settled in American law.

As to the history, ${ }^{2}$ I have a somewhat different perspective on both the work of Ruth Bader Ginsburg and the role of race in constitutionalizing

Copyright $\odot 2002$ California Law Review, Inc. California Law Review, Inc. (CLR) is a California nonprofit corporation. CLR and the authors are solely responsible for the content of their publications.

$t$ Professor of Law, University of Chicago Law School. I am grateful for the comments of Richard Epstein, Philip Hamburger, Catharine MacKinnon, and Geof Stone; the brainstorming help of Ed Baker, Mary Becker, Brian Bix, Enily Buss, Peggy Cooper Davis, Martha Fineman, Jill Hasday, Shira Kapplin, Sylvia Law, Nancy Levit, Linda McClain, Robert Post, Jane Rutherford, Carol Sanger, Buffie Scott, Kate Silbaugh, and Walter Wadlington; the reminiscences of Catherine May Bedell and the outstanding research assistance of Toby Heytens. Research support for this project came front the Amold and Frieda Shure Research Fund of the University of Chicago and the Class of I966 Research Professorship of the University of Virginia.

I. Between the tinie of the lecture in late November 2000 and its publication, one potentially significant change did occur. In Nguyen v. INS, 533 U.S. 53, 74 (200I) (O'Counor, J., dissenting), the Supreme Court upheld "legislative classifications based on sex" in a way that, according to dissenters including Ruth Bader Ginsburg, departed sharply from the precedent set forth in the "long line of cases spanning nearly three decades," which forms the centerpiece of Sullivan's lecture.

2. See Kathleen M. Sullivan, Constitutionalizing Women's Equality, 90 CaLIF. L. Rev. 735, $739-46$ (2002). 
women's equality. ${ }^{3}$ With respect to her contributions in this area, I am second to none in my admiration for Ginsburg; ${ }^{4}$ but I by no means think that she developed our current constitutional law of sex discrimination out of what Sullivan has called an empty kitchen. ${ }^{5}$ On the contrary, in cooking up her victories in Reed and its progeny, ${ }^{6}$ Ginsburg could make use of a number of useful ingredients already in the Supreme Court's kitchen. ${ }^{7}$ I have already given my extended inventory of the relevant contents of that kitchen elsewhere, ${ }^{8}$ but let me briefly summarize my version of the recipe and its main ingredients here. I do think, as Sullivan does, that the development of the constitutional law of sex discrimmation was path dependent, but not, as I see it, principally on constitutional race-discrimination law, instead on the statutory law of sex discrimination arising out of Title VII of the 1964 Civil Rights Act. It is thus path dependent on exactly what Sullivan correctly says American law traditionally holds back from, to wit government intervention into private discrimination: We began with a statutory prohibition against discrimination on grounds of sex by private employers and extended it in a rather directly path dependent way to constitutional prohibitions against discrimination on grounds of sex by government actors.

I do not deny the importance of analogies between race and sex discrimination. As is often the case when it comes to the influence of race on American law, however, the story of race's influence on constitutionalizing women's equality is more complicated than commonly acknowledged and has some unlikely and problematic heroes. Among the heroes I would include, alongside Sullivan's choice of litigator Ruth Bader Ginsburg, are the legislators responsible for Title VII's prohibition on sex discrimination in employment, an odd coalition of racist southern male and moderate

3. In a piece published shortly before Sullivan first delivered her Brennan lecture, I set forth at length my views on the development and scope of the Supreme Court's jurisprudence in this area. Mary Anne Case, "The Very Stereotype the Law Condemns": Constitutional Sex Discrimination Law as a Quest for Perfect Proxies, 85 ConNel. L. Rev. I447 (2000) [heremafter Case, "The Very Stereotype" 1 . Much of what I say, infra text accompanying notes 20-42, recapitulates in a brief and somewhat fragmentary way what I said there. I regret the repetition, but find it inpossible to avoid entirely in responding to Sullivan's markedly different view of the same body of law.

4. See, e.g., Case, supra note 3, at I450; Mary Anne C. Case, Disaggregating Gender from Sex and Sexual Orientation: The Effeminate Man in the Law and Feminist Jurisprudence, 105 YALE L.J. 1, 9-10 (1995) [hcremafter Case, Disaggregating Gender].

5. Sullivan, supra note 2, at 763.

6. Reed v. Rced, 404 U.S. 71 (1971).

7. She could also, as Michael Dorf's contribution to this symposium stresses, build on the work of over a century of activism by women's advocates. Michael C. Dorf, The Paths to Legal Equality: A Reply to Dean Sullivan, 90 CALIF. L. Rev. 791, 794-98 (2002).

8. See Case, supra note 3, at 1450-52, 1461-72 (giving a detailed account of the principal influences on the development of constitutional sex-discrimination law). 
northern female and Republican members of Congress led by Howard Smith of Virginia and Martha Griffiths of Michigan. ${ }^{9}$

Contrary to Sullivan and to the conventional wisdom, I do not think that Smith, as Chairman of the House Rules Committee, introduced "sex" into Title VII as a joke or simply as "a southern attempt to mcite a filibuster." ${ }^{10}$ Rather, like the many other southern White male legislators who voted for the addition of "sex," but agamst the Civil Rights Act as a whole, Smith understood quite well that, as Martha Griffiths put it in floor debate, "a vote against this amendment today by a white man is a vote against his wife, or his widow, or his daughter, or his sister."1l That is to say, Smith and other legislators who supported the addition of "sex" understood what the legal academy has subsequently come to call "intersectionality." 12 As they saw it, unless Congress included prohibitions on sex discrimination with those on grounds of race, color, religion and national origin, "the white woman of mostly Anglo-Saxon or Christian

9. Although Griffiths herself was a Democrat, the other women of the House who spoke in favor of the sex amendment included Republicans Katherine St. George of New York and Catherine May of Washington. The most liberal Democratic woman in the House, Edith Green, was the only woinan in Congress to oppose the sex amendment; she did not want to dilute the focus on race. And, according to Griffiths, who was a teller for the vote, "Inost of the amendment's supporters were southerners and Republicans." Carl M. Brauer, Women Activists, Southern Conservatives, and the Prohibition of Sex Discrimination in Title VII of the 1964 Civil Rights Act, 49 J. S. Hrst. 37, 51 (1983).

10. Sullivan, supra note 2 , at 763 . For a more detailed account of iny view of the meaning of the circumstances of the inclusion of "sex" in Title VII, see Mary Anne Case, From the Mirror of Reason to the Measure of Justice, 5 YALE J.L. \& HUMAN. 115, 124 (1993) (analogizing the relationship between Smith and the female congressional supporters of his sex amendment to a long history of female feminists' exploitation of arguments inade by men at least partly in jest).

11. 110 CoNG. REC. 2580 (1964) (statement of Chairman Howard Smith).

12. See generally Kimberlé Crenshaw, Demarginalizing the Intersection of Race and Sex, 1989 U. ChI. LEgal F. 139 (critiquing tendency in antidiscrimination theory and law to treat race and sex as inutually exclusive categories of experience and analysis, and urging a focus on their intersections). Ironically, Ruth Bader Ginsburg has revealed herself occasionally less conscious of imtersectionality. In recounting for the majority in United States v. Virginia ("VMT") the history of constitutionalizing women's equality in which she herself played so large a part, Ginsburg asserted, "[i]n 1971, for the first tine in our Nation's history, this Court ruled in favor of a woinan who complamed that her State had denied her the equal protection of its laws." 518 U.S. 515, 532 (1995). True, it was not until 1971 that the Coart held a woman had been deprived of equal protection on grounds of sex, but has Ginsburg forgotten that the person whose right to equal protection was most directly at stake in Brown v. Board of Education, 347 U.S. 483 (1954), was a girl, the Browns' daughter Linda? See, e.g., MARK V. Tushinet, Making Civil Rights Law 154 (1994). Like Mildred Jeter Loving, see Loving v. Virginia, 388 U.S. 1 (1967), and countless other woinen of color, long before 1971, Linda Brown was the beneficiary of a ruling by the Court that "her State had denied her the equal protection of its laws" on grounds of race. Virginia, 518 U.S. at 532. I am grateful to my former colleague John Harrison for first poimting out Ginsburg's faux pas as we both read the $V M I$ opimion on the day it came down. While Giusburg's slip of the pen is inerely embarrassing, intersectionality may have played a more simister role in the Miller and Ngzyen decisions. See Nguyen v. INS, 533 U.S. 53 (2001); Miller v. Albright, 523 U.S. 420 (1998). Consider the "ugly class and race iniplications [of a]llowing U.S. fathers to elect not to convey citizenship" on children they may conceive abroad. See Alex Aleinikoff \& Cornelia Pillard, Skeptical Scrutiny of Plenary Power: Judicial and Executive Branch Decision Making in Miller v. Albright, 1998 SuP. CT. REv. 1, 24 n.92. 
heritage [would be deprived of] equal opportunity before the employer"13 compared, not only with Anglo-Saxon Christian men (the intersectional category assumed to be virtually every employer's first choice), ${ }^{14}$ but also with men and women of every other race, ethnicity, and religion. Smith may have been a racist, but he had also been a sponsor of the Equal Rights Amendment ("ERA") since 1943 and was so supportive of the National Woman's Party ${ }^{15}$ that they called him their "Rock of Gibraltar."16 $\mathrm{He}$ would have been happy to see Title VII fail, but, if it were to pass, he did not want "his" women to take second place to men and women of other races.

Although Smith's concerns for sex equality in employment may have begun and ended with White women, Griffiths's clearly did not. In a series of intersectional hypotheticals, she invited Congress to consider the fate, in the absence of prohibitions on sex discrimination in employment, not only of White women, whom she posited as being put "down at the bottom of the list ... with no rights at all,"17 but also of Black women seeking to integrate traditionally male jobs such as that of longhaul trucker ${ }^{18}$ and professor of political science ${ }^{19}$ and traditionally White jobs such as dishwashers in fancy restaurants. ${ }^{20}$ As she later noted, "race discrimination in einployment would be only half eradicated if employment discrimination continued on the basis of sex." ${ }^{21}$ In her disquisition on the difficult history

13. 110 CoNG. Rec. 2583 (1964) (Statement of Rep. Rivers, South Carolina).

14. Clark Freshman and Mary Coombs are among those im the legal acadeiny who have drawn attention to the fact that "wealthy straight White inale" is no less an intersectional category than "poor Black lesbian;" indeed it may be the paradigm intersectional category, deviation from which, in any direction, tends to prompt discrimination. See, e.g., Clark Freshman, Whatever Happened to AntiSemitism: How Social Science Theories Identify Discrimination and Promote Coalitions Between "Different" Minorities, 85 CORNELl L. REv. 313, 337 (2000).

15. Griffiths was at least nominally a member of the National Wounan's Party ("NWP"). See, e.g., Leila J. Rupp \& Verta Taylor, Survival in the Doldrums: The American Women's RIGHTS MOVEMENT I945 TO THE I960S, at 177 (1987). The NWP was active in mobilizing support for the sex amendment, as well as for the ERA. The typical NWP member belonged to a group common in prior centuries, but now approaching extinction. She was a wounan quite radical on women's issues, but moderate to conservative on virtually all others; one whose chief coinplaint with the system was simply that it excluded her and differentiated her on grounds of sex. See Case, supra note 10, at 126-27.

16. See Jo Freennan, How "Sex" Got into Title VII: Persistent Opportunism as a Maker of Public Policy (citing 1:7 NWP BulletIN, Nov.-Dec. 1966, at 3), at http://www.jofreeinan.com/lawandpolicy/ titlevii.htm (last modified Sept. 14, 2001).

17. I10 CONG. REC. 2579 (1964).

18. Id.

19. Id.

20. Id. Black women activists were divided as to the desirability of the sex amendment. While Pauli Murray, also a strong ERA supporter, circulated a memorandum arguing, inter alia, that failing to include sex would hurt Black women, the President of the National Council of Negro Women, Dorothy Height, worried about weakening the bill and its chances for passage and helped persuade the Citizens Advisory Council on the Status of Woinen, of which she was a meinber, to take no position on the sex ainendment. See Cynthia Harrison, ON Account of Sex: The Politics of Women's Issues I945I968, at 180 (1988).

21. 112 CoNG. Rec. 13,689 (I966) (Statennent of Rep. Griffiths). 
of constitutionalizing women's equality, which she saw as most relevant to Title VII, Griffiths highlighted the efforts, not only of "Virginia Minor, native-born, free, white citizen of the United States,"22 but also of "Sojourner Truth, a Detroit woman,... the greatest of all the ... colored women ... among the suffragettes."23

Two years after the passage of the Civil Rights Act, Griffiths returned to the floor of the House to blast the EEOC for its failure to take prohibitions on sex discrimination in employment seriously. ${ }^{24}$ In part as a result of her prompting, the EEOC began to develop a more aggressive approach to sex discrimination, issuing guidelines prohibiting employment decisions "based on stereotype" and insisting that "individuals be considered on the basis of individual capacities and not on the basis of any characteristics generally attributed to the group."25

The Supreme Court first applied the resulting antistereotyping jurisprudence to sex in Title VII cases $^{26}$ and then carried it over rather directly to cases like Reed ${ }^{27}$ and Frontiero. ${ }^{28}$ These cases, like so many of the constitutional sex-discrimination cases Ruth Bader Ginsburg argued, were essentially einployment-discrimination cases, albeit not generally for the types of jobs or benefits covered by Title VII. What Mrs. Reed wanted, for example, was, in effect, a job, that of estate administrator for her deceased son; and what Ginsburg persuaded the Court to hold under the Constitution was, in essence, that being a man was not a Bona Fide Occupational Qualification ("BFOQ") for that job. Mrs. Reed's individual qualifications, not her sex, would henceforth determme whether she got the job.

The rather close analogy to statutory sex-discrimination cases was at least as important to both the reasoning ${ }^{29}$ and the result of Ginsburg's victories before the Court as the siguificant but, as Sullivan notes, imperfect, analogies to the Court's post-Brown race cases. The constitutional racediscrimination precedents most directly on point for the development of constitutional sex-discrimination law (although not explicitly relied upon by the Court) were those from the heyday of separate but equal, insisting that exceptional Black people, like exceptional women a half century later,

22. 110 CONG. REC. 2580 (1964).

23. Id. Griffiths, herself from Detroit, also credited the contributions of both White men and men of color to women's suffrage. Id.

24. See 112 CONG. REC. 13,689 (1966).

25. EEOC Guidelimes on Discrimination Because of Sex, 29 C.F.R. $\$ 1604.2$ (a)(ii) (2001).

26. The earliest Supreme Court reference to sex stereotyping appeared in Justice Marshall's 1970 concurrence in Phillips v. Martin Marietta Corp., 400 U.S. 542 (1971), a Title VII case. The term entered the Court's constitutional vocabulary in Frontiero v. Richardson, 411 U.S. 677 (1973).

27. Reed, 404 U.S. at 71.

28. Frontiero, 411 U.S. at 677.

29. As 1 have noted before, see Case, supra note 3, at 1463-64, antistereotyping doctrine developed in lower court cases, some of which, by combining constitutional and statutory questions of sex discrimination, impelled courts to apply the same standards to both. See, for example, Sail'er Inn $v$. Kirby, 485 P.2d 529 (Cal. 1971), which was cited with approval by the Supreme Court. 
be afforded opportunities "on the basis of individual capacities and not on the basis of any characteristics generally attributed to the group."

As I have argued before, ${ }^{31}$ a significant additional factor that may have moved the Court to be especially receptive to Ginsburg's antistereotyping arguments was that they were first presented at the high watermark of the Court's concern with the constitutionality of all irrebuttable presumptions, all general rules that did not admit specific exceptions. It was as irrebuttable presumptions that the Court treated the rule in Reed mandating the selection of fathers over mothers and those in favor of the dependency of wives at issue in several Ginsburg cases..$^{32}$ It was also as irrebuttable presumptions that the Court treated the rule in Stanley $v$. Illinoi ${ }^{33}$ presuming nonmarital fathers to be unfit and that in LaFleur ${ }^{34}$ requiring pregnant teachers to depart the classroom early in their pregnancy. But presumptions related to sex and gender such as these were far from the only ones that concerned the Court at the time. Across a wide spectrum of subject areas and predicate constitutional provisions ranging from First Amendment overbreadth doctrine to the death penalty to voting rights, the period in which our modern constitutional law of sex discrimination developed represented one extreme of the Court's constitutional concern about making room for individual exceptions..$^{35}$ As I have previously noted:

A sea of concern about the constitutional difficulties with overbroad rules and inperfect proxies swept over the Court in precisely that time period during which the current constitutional law of sex discrimination was developing. At the time of its development, sex discrimination doctrine was one of many related flourishing life forms in this sea, but, by the time the sea receded

30. See, e.g., Missouri ex rel. Gaines v. Canada, 305 U.S. 337, 351 (1938). The Court held: Here petitioner's right was a personal one. It was as an individual that he was entitled to the equal protection of the laws, and the State was bound to furnish him ... facilities ... substantially equal to those which the State there afforded for persons of the white race, whether or not other negroes sought the same opportunity.

Id: McCabe v. Atchison, Topeka \& Sante Fe Ry. Co., 235 U.S. 151, 161-62 (1914) (reaching a similar conclusion with respect to the provision of sleeping cars for Blacks on segregated trains).

31. For further discussion, see Case, supra note 3, at 1466-69.

32. See, e.g., Califano v. Goldfarb, 430 U.S. 199 (1977); Weinberger v. Wiesenfeld, 420 U.S. 636 (1975); Frontiero v. Richardson, 411 U.S. 677 (1973).

33. 405 U.S. 645 (1972).

34. Cleveland Bd. of Educ. v. LaFleur, 414 U.S. 632 (1974) .

35. Interestingly, with the equal protection holding of Bush v. Gore, 531 U.S. 98 (2000), the Court may have swung the pendulum as far as possible in the opposite direction: The Court's premise in the era of heightened scrutiny for most irrebuttable presumptions was that equal protection and due process required that if there can be a standard, there must be a standard, there may not be a rule. In Bush v. Gore, the majority instead insisted that if there can be a rule, there must be a rule, there may not be a standard. The turning point may have been Rehnquist's majority opinion in Weinberger v. Salfi, 422 U.S. 749 (1975). "Rehnquist had long been of the view, hitherto expressed in dissent, that what his brethren considered impermissible, irrebuttable presumptions were what ... [had been] prized as lawgeneral rules announced in advance and ... applied" without exception or special consideration of individual circumstances. Case, supra note 3 , at 1468 n. 109. 
toward the end of the 1970s, only sex discrimination doctrine had developed the hard skeleton necessary to insure both a clear fossil record and the continuing viability of the organism. ${ }^{36}$

Sullivan, like most scholars, attributes the Court's announced intermediate scrutiny standard to the difficulties of "adapting the law of race discrimination for sex discrimination." ${ }^{\text {"37 }}$ It remains my view, however, that the announced components of the intermediate scrutiny standard, that is, inquiry into whether a practice is "substantially related to important governmental objectives," Court sex-discrimination decision. ${ }^{39}$ Instead, the bulk of the work in these decisions has been done by what readers of the opinions may be tempted to treat as mere decorative rhetorical flourish: the proposition that there are constitutional objections to "gross, stereotyped distinctions between the sexes," 40 that is to "classifications based on sex ... premised on overbroad generalizations." 41

If one shifts the focus away from the traditional requirements of heightened scrutiny toward questions of stereotyping and the quest for perfect proxies, the causal arrows and direction of path dependence between the Supreme Court's race and sex jurisprudence become quite coinplicated and interesting. No longer does sex appear to be a pale imitation of race. ${ }^{42}$ Rather, the notion that it is a wrong of constitutional dimensions to stereotype members of protected classes, that is, to use a suspect classification as an imperfect proxy, seems to make its way on the modern Supreme Court from sex-discrimination to race-discrimination cases. ${ }^{43}$ Consider, for example, the recent emphasis in voting rights cases on the "unjustified

36. Case, supra note 3 , at 1466.

37. Sullivan, supra note 2, at 742. Sullivan characterizes the "intermediate scrutiny" standard for sex as resulting from the Court's decision to "spli[t] the difference" when faced with "analogical crises" in comparing sex to race. Sullivan, supra note 2 , at 745.

38. See, e.g., Miller v. Albright, 523 U.S. 420, 434 n.11 (1998).

39. Nguyen v. INS, 533 U.S. 53 (2001), is no exception. Rather, the Nguyen inajority can be seen to conform or depart from precedent under either formulation of the relevant test, depending on whether the majority or the dissent is more convincing. The majority set forth its arguments under both formulations of the test: it considered a sex-based distinction based on women's giving birth (i) not based on a stereotype (since it categorically excludes males) and (ii) related to the interest in providing an opportunity to form a relationship with one's child. According to the dissent, the majority fails both by relying "only on an overbroad sex-based generalization," $i d$. at 86 ( $O$ 'Counor, J. dissenting), and by failing to identify a close enough fit with a sufficiently important governmental interest. Indeed, the dissenters correctly describe the latter failure as far lcss contestable than the former. After all, no inan has yet given birth to a child, but the case for a close connection between this sex-based generalization and any identified important governmental interest is less clear. For a sense of how difficult it would have been for the Court, rather than Congress, to reach a satisfactory alternative result to that of the majority in Nguyen, see Case, supra note 3, at 1479-83.

40. Frontiero v. Richardson, 411 U.S. 677, 685 (1973).

41. Schlesinger v. Ballard, 419 U.S. 498, 507 (1975).

42. No pun intended.

43. For further discussion, see Case, supra note 3, at 1454-55. 
racial stereotyping" involved in using "race as a proxy for political characteristics," even when it may be an overwhelmingly accurate proxy. ${ }^{44}$

Despite its association up to now with conservative Justices' insistence on colorblindness, increasing path dependence of race on sex cases may paradoxically hold some promise for proponents of racial affirmative action. Up to now, the quest for perfect proxies, while animating both raceand sex-based affirmative action analysis, has led to diametrically opposed results: in sex cases, but emphatically not in recent race cases, ${ }^{45}$ the Court seems willing to recognize that $100 \%$ of the inembers of the historically subordinated group, even those not demonstrably inaterially affected by it, are subject to ambient discrimination on the basis of their membership in the group. One reason for this may be that, far from being "fuzzier [than] records of past official discrimination" 46 against Blacks, records of discrimination against women $\mathrm{m}$ employment in cases before the Court were comparatively clear. The sex-based affirmative action blessed by the Court followed closely on de jure restriction or exclusion of women from job opportunities. ${ }^{47}$ Thus, the perfection of the proxy (that is, the absence of an exception to the exclusion) could be shown more clearly than it could in race cases, where, at least since the fall of Jim Crow, exclusion was not de jure and thus not as demonstrably categorical. Perhaps it is too much to hope that the Court's announced continued willmgness, a generation after most de jure exclusions of women from employment or public education have ended, to uphold sex distinctions if they are "used to compensate women 'for particular economic disabilities they have suffered, ... promote equal employment opportunity,' [or] advance full

44. Bush v. Vera, 517 U.S. 952, 967-69 (1996) (plurality opinion).

45. See, e.g., Adarand Contractors, Inc. v. Pena, 515 U.S. 200 (1995).

46. Sullivan, supra note 2 , at 746.

47. Sometines the exclusion was ongoing. For example, regulations excluding women from combat positions were used to justify longer proinotion times for women in Schlesinger v. Ballard, 419 U.S. 498 (1975).

The fact that, notwithstanding the combat exclusion, some woinen could and did get pronoted in the time allowed men did not mean that the proxy was imperfect, because the exclusion still affected all woinen, even those who by extraordinary effort, luck, or skill managed to overcoine its handicap. Similarly, if a rule says a woman inust be twice as good as a inan to be promoted, and she is twice as good, the discriminatory rule will not have changed the outcome in her case, but she will still not have been exempt from the application of the rule.

Case, supra note 3 , at 1460 . With this structure of analysis in mind, it is easier to see how some affirmative action schemes for women can rely on the perfect proxy of societal discrimination against women, notwithstanding that many feınale beneficiaries may not have suffered identifiable harms from discrimination. As women, they remain surrounded by the ambient level of discrimination against them; just like the military women in Ballard, they may be excluded froin jobs they neither need nor want, or they may succeed despite the exclusion, but they will have been excluded nevertheless. Id.; $c f$. Civil Rights Act of 1991, 42 U.S.C. $§ 1981$ a (1994) (amending Title VII to give for the first time a cause of action to victims of discrimination even if no employment outcone in their case was altered by the discrimination). These amendinents may provide some acknowledgement that the burden of having to be twice as good is a difficult and unjust one, even to those who can meet it. 
development of the talent and capacities of our Nation's people"48 will carry over to race. Yet, this might be the best way of dissolving the paradox of antistereotyping analysis thus far leading the Court's jurisprudence in such diametrically opposed directions for race and sex. ${ }^{49}$

In addition to complicating the relationship between race and sexdiscrimination doctrine, an emphasis on antistereotyping (rather than on the conventional components of intermediate scrutiny analysis) makes the constitutionalizing of women's equality under U.S. law in the final quarter of the twentieth century ${ }^{50}$ a far more rulelike and less standard-like enterprise. As Sylvia Law put it, the "emperor" of equal protection law is generally seen to have three garments: red for stop, yellow for caution, and green for go, equivalent to strict, intermediate, and rational basis scrutiny. ${ }^{51}$ In questioning this conventional wisdom, I am not suggesting that the emperor has no clothes, rather that what may have been seen as a fluid yellow garment is instead more akin to a rigid suit of armor: it is a rule, not a standard. Moreover, it is exactly the rule that proponents of the ERA, from Ginsburg to Pauli Murray, hoped for from that amendment. ${ }^{52}$ Interestingly, in light of Sullivan's emphasis on the text of other constitutions' sexequality guarantees, both the Fourteenth Amendment and the ERA (that is, both the actual and the hoped-for U.S. constitutional texts) make general guarantees of equality but produce specific antidiscrimination rules similar to those set forth in the text of Title VII. Though Sullivan may search around the world for better texts, the evidence she presents shows that a textual provision guaranteeing women's equality is neither necessary nor sufficient. The American Constitution also "lacks a provision explicitly declaring the equality of the" ${ }^{253}$ races, or indeed of any other explicitly named classifications of individuals, with the exception of "citizens of each

48. United States v. Virginia, 518 U.S. 515, 533-34 (1995).

49. In her opinion in Adarand, Justice Ginsburg discussed the lingering effects of discrimination and soine lessons froin sex cases concerning the fine line between helpful and harmful affirmative action. See Adarand, 515 U.S. at 275 (Ginsburg, J., dissenting).

50. That is, at least from Frontiero v. Richardson, 411 U.S. 677 (1973), until the decision in Ngryen v. INS, 533 U.S. 53 (2001).

51. Comment on April 1997 New York University faculty workshop presentation of Case, "The Very Stereotype", supra note 3.

52. "There is uo practical difference between what has evolved and the ERA" said Ruth Bader Ginsburg to a student audience (admittedly before Nguyen came down). See Jeffrey Rosen, The New Look of Liberalism on the Court, N.Y. TMES MAG., Oct. 15, 1996, at 60, 65; see also Barbara A. Brown, Thomas I. Emerson, Gail Falk \& Ann E. Freedman, A Constitutional Basis for Equal Rights for

Women, 80 YALE L.J. 871, 893 (1971). This influential article on the meaning of the ERA insisted:

So long as the law deals only with a characteristic found in all (or some) women but no men, or in all (or some) men but no women, it does not ignore imdividual characteristics found in both sexes im favor of an average based on one sex. Hence such legislation does not, without Id. nore, violate the basic principle of the Equal Rights Amendment.

53. Sullivan, supra note 2 , at 735. 
state. ${ }^{\circ 4}$ We have staked our textual fate on a broad undifferentiated equality guarantee; to use one of Sullivan's dichotomies, the guarantee is general, not specific. ${ }^{55}$

Although, by quoting the sex-equality guarantees of a number of the world's constitutions, Sullivan frames her inquiry to a certain extent in comparative law terms, I will by and large not take up this comparative gambit in my brief commentary, but will focus on U.S. law. ${ }^{56}$ Framing the constitutional equality of the women of Afghanistan, to take but one timely example, presents problems well beyond the scope of this Essay. Cultural questions with respect to both women and constitutionalisin not only would influence the choice of constitutional text, but would tend to dominate the interpretation of that text and the extent to which it offered any meaningful guarantee of such equality as it promises. Moreover, some of the more fundamental questions presented by a comparative inquiry would take us much too far afield. Consider, for example, the question of how constitutional guarantees can build on and how they may be limited by religious law. While this is no longer a pressing question for the United States, I will not deny (although I will not pursue here either) the potential relationships between Christian concepts of equality and American constitutionalism. Were I to pursue this vein, I might begin by observing that, at least of late, under U.S. constitutional law (just as, for Paul, "in Christ") "there is neither Jew nor Greek, there is neither slave nor free, there is neither male nor female, for ... all [are] one." ${ }^{.57}$ Our legal system has moved beyond a jurisprudence of status or group rights or of equality in separate spheres to one of abstract universalism and imdividualisin in ways consistent with and important to our current constitutionalizing of women's equality. ${ }^{58}$ But among the important questions posed by a serious and detailed inquiry into the comparative constitutionalism of women's equality

54. See U.S. CONST. art. IV, $\S 2$. Even the infaunous specification of "male inhabitants" in the Fourteenth Amendment does not, as a formal matter, guarantee thein equal voting rights, so much as provide penalties for a departure from such equality, penalties unthinkable if such equality really was guaranteed.

55. Sullivan, supra note 2 , at 747 . In part because of my commitment to antidifferentiation in addition to antisubordination, see infra note 106 , I rejoiee in the language's generality, which may, inter alia, mitigate against a tendency to seek equality in separate spheres.

56. In rejecting a comparative law focus, I do not wish to turn my back on the broader world. I had always hoped to see the Violence Against Women Act rely on the Define and Punish Clause. See U.S. CoNST. art. I, $\S 8$, c. 10 (granting Congress the power "[t]o define and punish Piracies and Felonies committed on the high Seas, and Offenses against the Law of Nations"). The "male protection racket" of violence could be fruitfully analogized to piracy, and violence against women could be seen as an offense against the law of nations as embodied in treaties and customary international law. See, e.g., Kadic v. Karadzic, 70 F.3d 232 (2d Cir. 1995).

57. Galatians 3:28 (New Anerican Standard Bible).

58. I have discussed my view of this tendency as it relates to American constitutional equality norms at length, and will not belabor it here. See generally Mary Anne Case, Unpacking Packagc Deals: Separate Spheres Are Not the Answer, 75 Denv. U. L. Rev. I305 (I998). 
(one, presented, if not squarely in the Afghan case, ${ }^{59}$ in other Islamic countries $^{60}$ ) is how possible it might be to imagine a satisfactory constitutionalism of equality in separate spheres. ${ }^{61}$ Can one imagine, for example, workable constitutional guarantees of women's learning, exercising, working, competing, speaking, trading, politicking, and governing in a world of women parallel to and equal with the world of men, with women doctors treating women patients, women spectators cheering on woinen athletes, ${ }^{62}$ and women judges deciding women's cases? This would be a radically different form of separate spheres than that familiar to us (and thus far rejected by our constitutional law), which tends to feature men and women in complementary roles ${ }^{63}$ rather than in parallel universes.

A focus on comparative constitutional jurisprudence might remind us, however, that even constitutional guarantees framed in universal terms may have special import for women's lives and need to be interpreted with this in mind. Thus, im different but related ways, French Revolutionary theorist Olympe de Gouges and modern Kuwaiti poet-economist Sheikha Dr. Souad M. Al-Sabah particularize woinen's need for freedom of speech: "It is not democracy when a man can talk about politics/without anyone threatening him," wrote Dr. Souad, "Democracy is when a woman can talk of her lover without/anyone killing her." 64 "Free communication of thoughts and opinions is one of the most precious rights of woman, since this liberty assures the legitimate paternity of fathers with regard to their children," wrote Mme de Gouges in her 1791 Declaration of the Rights of Woman and the Female Citizen." "Every fernale citizen can therefore

59. Although my understanding is that pre-Soviet Afghanistan, more than most Muslim countries, integrated professional women into the public sphere, the Taliban regime went further than any other in seeking to exclude them. See, e.g., Jan Goodwin \& Jessica Neuwirth, The Rifle and the Veil, N.Y. TMES, Oct. 19, 2001, at A19.

60. See, e.g., Elizabeth Warnock Fernea, In Search of Islamic Feminism: One Woman's GLobAL JouRNEY 338-43 (1998) (describing continued sex segregation combined with mereasing opportunities for woinen in Saudi Arabia, with women-only universities, women-only shopping malls funded by female investors, and "women ... work[mg] in offices separate froin men [and] ... serv[img] each other ... in schools, banks, medical and dental clinics").

61. I have already repeatedly expressed my own personal normative opposition to such an approach. See, e.g., Case supra note 3, at 1473-77; Case, supra note 58, at 1313-20.

62. See, e.g., Robin Wright, The Last Great Revolution: Turmoil and Transformation IN IRAN 133-35 (2000) (describing a Tehran basketball game played, coached, refereed, and watched by woinen only).

63. See Francisco Valdes, Queers, Sissies, Dykes, and Tomboys: Deconstructing the Conflation of "Sex," "Gender" and "Sexual Orientation" in Euro-American Law and Society, 83 Cal.IF L. Rev. $1,211-44$ (1995) (setting forth an optinistic view of the possibilities for equality in separate spheres in a chapter on the Native American berdache tradition).

64. Jan Goodwin, Price of Honor: Muslim Women Lift the Veil of Silence on the ISLAMIC WORLD 154 (1994) (quoting a poem by Sheikha Dr. Souad M. Al-Sabah).

65. Olympe de Gouges, Declaration of the Rights of Woman and the Female Citizen, in 1 Women, the Family and Freedom: The Debate in Documents 104, 106 (Susan G. Bell \& Karen M. Offen eds., 1983). For the origimal French text, see OLYMIPE DE Gouges, ECRITs PolitiQues I 788- 
freely say: 'I am the mother of a child that belongs to you,' without a barbaric prejudice forcing her to conceal the truth ...."

Where in U.S. law do we observe the need to inflect generally applicable rights by sex as part of constitutionalizing women's equality? Consider two examples, one backward looking, one more forward looking. The first is the move away from a substantive due process focus on freedom of contract (of interest to both sexes, pace Muller v. Oregon, ${ }^{67}$ but particularly relevant to men in the Lochner era) toward reproductive freedom (of interest to both sexes, ${ }^{68}$ as Catharine MacKinnon cogently argues, but most obviously and immediately important to women in the modern era). The shift in emphasis toward women's liberties is particularly visible in the transition from Justice Blackmun's Roe v. Wade ${ }^{69}$ opinion to the plurality opmion in Casey. ${ }^{70}$ Blackunun is often criticized for framing the abortion right as almost as much the doctor's as the preguant patient's. But the Casey plurality makes clear: "What is at stake is the woman's right to make the ultimate decision ...."."71

Second, consider how the constitutional right to bodily integrity may also be inflected differently for males and fenales, as dramatically illustrated by the troubled history of the criminal prosecution of state Judge David Lanier for depriving a number of female employees and litigants of their constitutional rights by sexually assaulting them in chambers. ${ }^{72}$ Lanier was prosecuted under 18 U.S.C. $\$ 242$, which criminalized willful "deprivation of any rights ... protected by the Constitution" committed by any person "under color of any law." "73 Before a unanimous Supreme Court vacated their decision, ${ }^{74}$ the Sixth Circuit mitially held en banc that Lanier's conviction could not stand because, although his conduct was clearly wrongful, no prior case had placed Lanier on notice that sexual assault by a judge would constitute a violation of the broadly worded federal

I79r, at 204-15 (1993). Mme de Gouges suffered what may be the uitimate deprivation of free speech-she was guillotined for the pamphlets she had written.

66. Id.

67. 208 U.S. 412 (1908).

68. See Catharine A. MacKinnon, Feminism Unmodified: Discourses on life and Law 97-99 (1987).

69. 410 U.S. 113 (1973).

70. Planned Parenthood of Southeastern Pa. v. Casey, 505 U.S. 833, 877 (1992).

71. Id. For a further indication that, in addition to giving reproductive rights center stage among implied fundamental rights, American jurisprudence has also increasingly defined reproductive rights to highlight women's concerns, consider the progression froin Skinner v. Oklahoma, 316 U.S. 535 (1942) (protectimg an individual inan's right to reproduce), through Griswold v. Connecticut, 381 U.S. 479 (1965) (protecting a couple's reproductive choices), through Roe v. Wade, 410 U.S. 113 (1973) (protecting a woinan's right to obtain, and a physician's to perform, an abortion), to Casey.

72. See United States v. Lanier, 520 U.S. 259, 261 (1997).

73. 18 U.S.C. $\$ 242$.

74. Lanier, 520 U.S. at 261. 
statute. ${ }^{75}$ Prior cases establishing the scope of the law had tended to deal with the sort of assault to bodily integrity more commonly perpetrated on males, such as assaults on prisoners by their guards. ${ }^{76}$ If beatings, particularly by strangers, are the paradigm violation of bodily integrity for males, however, rape, particularly by an acquaintance, may be the paradigm such violation for females. The Sixth Circuit made much of the fact that the United States had charged Lanier only with unconstitutional deprivation of his victims' liberty, not with "a gender-based crime for sexual assault involving discrimination against or oppression of women in violation of the Equal Protection Clause."77 The real equal protection violation will occur not when a judge rapes a woman, but when the law fails to take this violation as seriously as it takes nonsexual assaults perpetrated on males, however. ${ }^{78}$ The lesson of Lanier ought not to be an insistence on "judicial recognition of special protections for women alone,"79 but increased judicial recoguition, consistent with the Lanier prosecution's strategy, that women, like men, are constitutionally entitled to liberty.

This does not mean that I would oppose recognition of women's disproportionate vulnerability to certain harms, only that my preferred method of doing so might be what (conflating two of Sullivan's categories) I will call symbolic or hortatory asymmetry rather than legally enforced asymmetry. Let me illustrate this concept with three recent examples (the first two of wlich had constitutional difficulties for unrelated reasons): ${ }^{80}$ the civil

75. United States v. Lanier, 73 F.3d 1380, 1388 (6th Cir. 1996), vacated by 520 U.S. 259 (1997).

76. See, e.g., id. at 1414 (Daughtrey, J., dissenting).

Presumably, the majority would have no qualms in reaffirming the principle that prisoners have a constitutional right not to be assaulted by, or at the direction of their jailers .... That same majority, however, can now find that the commensurate right to freedom froin a willful sexual assault at the hands of a sitting judge has not been 'made specific' by prior court decision, solely because no Supreme Court case has yet explicitly involved a factual situation with a judge who so dishonored his profession or who sunk to such levels of depravity as has the defendant in this case.

Id.

77. Id. at 1383.

78. One reason for uncertainty as to whether this violation will occur is that the Supreme Court, while unanimously reversing the Sixth Circuit, left many crucial issues open on remand and Lanier, by fleeing the country, prevented consideration of those issues by the court below. For further discussion, see Case, supra note 3 , at 1474 \& n.135.

79. See Mary-Christine Sungaila, Litigating Women's Rights as Human Rights: The Case of United States v. Lanier, 7 S. CAL. REv. L. \& WoMEN's STud. 329, 329, 331-32 (1998) (quoting one of Lanier's victims as testifying to her "rights as a human being and as a citizen" and noting that the prosecution's litigation "strategy focused on human dignity and rights, and did not depend on judicial recognition of special protections for women alone"). Sungaila reports the good news that another judge prosecuted in the Sixth Circuit for crimes similar to Lanier's, whose case had been held pending the Supreme Court's Lanier decision, has been ordered to report to prison. Id. at 351 .

80. VAWA for exceeding congressional authority under either the Commerce Clause or Section Five of the Fourteenth Amendment in United States v. Morrison, 529 U.S. 598 (2000); the pornography ordinance as a First Amendment violation in American Booksellers Ass' $n$ v. Hudnut, 771 F.2d 323, 324 (2d Cir. 1985), reh'g denied, 475 U.S. 1132 (1986). No suit has yet been brought against the Harlem Young Women's Leadership Academy. 
remedy portion of the Violence Against Women Act ("VAWA"), ${ }^{81}$ the MacKinnon-Dworkin antipornography ordinance, ${ }^{82}$ and the Harlem Young Women's Leadership School. Neither statute is sex-respectimg. Despite its title, VAWA offered civil remedies regardless of sex to both male and female "victims of crimes of violence motivated by gender." MacKinnon-Dworkin ordinance also offered civil remedies to victims regardless of sex: although the statute began by defining "pornography" as "the graphic sexually explicit subordination of women ...,"84 it went on to provide that "the use of men, children, or transsexuals in the place of women ... shall also constitute pornography under this section." ${ }^{" 85}$ Finally, admission to the Harlem Young Women's Leadership School does not appear to be sex-respecting either; male as well as female students are free to apply for admission, ${ }^{86}$ but it happens that no male student has yet applied ${ }^{87}$

All three examples are, in a sense, counterpoints to the many old statutes written with male nouns and pronouns exclusively and then amended or clarified to say "he" includes "she" and "man" includes "woman." Although the operation of the law is sex-neutral, its expressive function highlights the centrality of women's concerns to the statutes' drafters. Through this hortatory asymmetry, they send the message that they are explicitly centered on promoting women's equality.

More hortatory asymmetry could be an important new wrinkle in the progression from sex-respecting rules usually favoring men (of the sort upheld by the Supreme Court before Reed) ${ }^{88}$ to formally sex-neutral rules often favoring men (of the sort blessed by the Court in cases since Reed), ${ }^{89}$ to sex-neutral rules more often favoring women. Associated with this progression is an increasing realization that some rules that are not sexrespecting may not in any meaningful, non-formalistic sense be sexneutral. ${ }^{90}$ For example, neither a law that licenses marital rape by either spouse regardless of sex nor one that criminalizes marital rape by either

81. As Judith Resnik reminds us, "the bulk of VAWA survives and thrives," continuing to provide funding and support for antiviolence programs. See Judith Resnik, Categorical Federalism: Jurisdiction, Gender and the Globe, 111 YALE L.J. 619, 642 (2001).

82. Hudnut, 771 F.2d at 324 (citing INDIANAPOLIS, IN. CODE $\S 16(1984)$ ).

83. Violence Against Women Act of 1994, Pub. L. No. 103-322, §13891(a), 108 Stat. 1796.

84. See Hudnut, $771 \mathrm{~F} .2 \mathrm{~d}$ at 324 . The statute goes on to set detailed conditions as to which sexually explicit subordinating words or pictures qualify. Id.

85. Id.

86. And, in principle, males as well as females can learn about and promote young women's leadership, as females have learned about and promoted that of young $\mathrm{men}$ for centuries.

87. For further discussion, see Case, supra note 3, at 1486.

88. See, e.g., Goesaert v. Cleary, 335 U.S. 464 (1948) (upholding law excluding women not related to male proprietor from tending bar).

89. See, e.g., United States v. Virginia, 518 U.S. 515 (1995) (holding the admission of women to a well-funded state-sponsored military school a sufficient remedy, notwithstanding findings that few women would apply and that nothing comparable had been made available to women).

90. For further discussion, see infra text accompanying note 108. 
spouse is sex-respecting. Yet, because of the overwhelmingly disparate impact on men and women (since most perpetrators and few victims of marital rape are men), it sounds odd to describe such laws as "sexneutral." One way of promoting women's equality through non-sexrespecting rules, as I have previously argued, ${ }^{92}$ may be to more often take typical women's experiences (rather than men's) as the model on which a rule is based, as the Family and Medical Leave Act ("FAMLA") to some extent does by assuming that all workers do indeed have what most woinen in the workforce have long had: care-giving responsibilities in the family in addition to their paid employment. ${ }^{93}$ In their hortatory asymmetry, statutes like VAWA ${ }^{94}$ go one step beyond FAMLA. Both FAMLA and VAWA shape their non-sex-respecting rules around problems presently facing many more women than men (respectively family care-giving obligations conflicting with paid work and gender-motivated violence). But, because statutes like FAMLA use sex-neutral language throughout (as do marital rape statutes that speak of what one "spouse" does to another) they may risk submerging awareness of the overwhelming disparate impact of certain acts or laws on women. By contrast, as Sullivan acknowledges, statutes like VAWA highlight a "special solicitude for the needs of specific subordinated groups" notwithstanding the "formally symmetrical criteria" they apply. ${ }^{95}$

The example of hortatory asymmetry is only one of many crosscutting complications one might bring to the five axes for jurisprudential choice Sullivan identifies. In addition to bringing together axes Sullivan tends to discuss in isolation, I would also urge distinguishing some that she equates with one another. ${ }^{96}$ For example, Sullivan sees the ehoice "between generality and specificity" as equivalent to "an old debate... between legal rules and standards ... affect[ing] the jurisdictional or institutional allocation of discretion," with "[s]pecificity [being] more directive and restraining, tying future interpreters' ... hands." ${ }^{.97}$ But an examination of precisely our constitutional law of sex discrimination indicates that the specific-general axis is not at all equivalent to that of rule-standard. What has governed the last quarter century of the law of equal protection on

91. For further discussion, see generally Robin L. West, Equality Theory, Marital Rape and the Promise of the Fourteenth Amendment, 42 FLA. L. REv. 45 (1990).

92. See generally Mary Anne Case, Two Cheers for Cheerleading: The Noisy Integration of VMI and the Quiet Success of Virginia Women in Leadership, 1999 U. CHI. LeGAL. F. 347 [hereinafter Case, Two Cheers]; Case, Disaggregating Gender, supra note 4, at 102-05.

93. 29 U.S.C. $\S \S 2601,2611$ (1994).

94. Violence Against Women Act of 1994, Pub. L. No. 103-322, 108 Stat. 1902 (codified in scattered sections of 28 U.S.C. and 42 U.S.C.).

95. Sullivan, supra note 2 , at 751 .

96. Space constraints unfortunately prevent me froin addressing all of Sullivan's axes in this Essay.

97. Sullivan, supra note 2 , at $747-48$. 
grounds of sex is, as I have previously argued, ${ }^{98}$ a rule, to wit, that sexrespecting rules will be held unconstitutional if they are found to be based on stereotypes. ${ }^{99}$ This rule is specific only to the extent that it concerns sex; in every other respect it is entirely general. But it is a rule, not a standard. It should satisfy and constrain the most rigid of formalists, although, like all rules, it has some fuzziness around the edges. ${ }^{100}$

By contrast, although Sullivan correctly describes the CEDAW provision she quotes as "highly specific," it is not at all rulelike; it is necessarily a standard, because it is difficult to tell exactly which

distinction[s], exclusion[s] or restriction[s] made on the basis of sex ... ha[ve] the effect or purpose of impairing or nullifying the recognition, enjoyment or exercise by women, irrespective of their marital status, on a basis of equality of men and women, of human rights and fundamental freedoms in the political, economic, social, cultural, civil or any other field. ${ }^{101}$

Another way of putting this difficulty is that the CEDAW provision asks but does not and cannot answer Catharine MacKinnon's question of whether the practice at issue contributes to the subordination of women or not. Mackinnon acknowledges this question to be "more jurisprudential than formulaic," that is, more standard-like than rulelike, and hence not aimed to "produce determinate outcomes in particular cases." 102 She offers her question as a way to avoid another axis for jurisprudential choice, one Sullivan's lecture manages to avoid mentioning, although it has long been

98. See Case, supra note 3, at 1449.

To determine whether there is unconstitutional sex discrimination, one need generally ask only two questions: 1) Is the rule or practice at issue sex-respecting, that is to say, does it distinguish on its face between inales and females? and 2) Does the sex-respecting rule rely on a stereotype [that is, an overbroad generalization]? ... Of course, in theory, a "No" answer [to the first question] does not end the inquiry. Instead, it triggers mquiry into constitutional disparate impact, with the next set of questions being the following: (a) Does the practice have a disparate impact on one sex?, and (b) If yes, was the practice adopted 'because of, and not im spite of this disparate impact? Notoriously,... in practice the Court has seen only sex-respecting rules as denying equality on grounds of sex.

Id. at $1449 \&$ n. 12 .

99. Nguyen v. INS, 533 U.S. 53 (200I), may have changed the emphasis in antistereotyping jurisprudence, but the inajority still insisted that to distinguish between male and female parents with respect to conveying citizenship on nonmarital children is not to rely on stereotypes. First, the "basic biological difference[]" that only women bear children is a "real one." Id. at 73. Secondly, at least in the majority's view, reliance on this perfect proxy for knowledge that one has produced a child showed no "disrespect for either class." Id.

100. For example, consider laws distinguishing on the basis of pregnancy. Are they sexrespecting? A majority of the Supreme Court notoriously held that they were not, since, as a formal matter, they divided the world, not by sex, but "imto two groups-pregnant women and nonpregnant persons. While the first group is exclusively fenale, the second includes members of both sexes." Geduldig v. Aiello, 417 U.S. 484, 497 (1974).

101. Sullivan, supra note 2, at 748 (quoting Convention on the Elimination of All Forms of Discrimination Against Women, Dec. 18, 1979, 1249 U.N.T.S. 13, I6 (art. 1) (entered into force Sept. 3, 1981)).

102. MacKinnon, supra note 68 , at 40. 
the bugaboo of feminist legal theory, the sameness-difference axis. ${ }^{103}$ In addition to sameness-difference, feminist jurisprudence has historically wrestled with a whole series of axes that have points of overlap with Sullivan's symmetry-asymmetry, but cannot easily be reduced to it. Among these are not only classification-class and formal-substantive, ${ }^{104}$ but also antidifferentiation-antisubordination, antidiscrimination-equality, and exception-rule (for example, should the focus be on the average person or the exceptional person in any given class). ${ }^{105}$

While space does not permit a full exploration of all axes, let me briefly address one: As to antidifferentiation-antisubordination, one of the principal open questions $\mathrm{m}$ U.S. law is whether separate but equal spheres for the sexes (that is, spheres that differentiate but do not subordinate) can ever be good enough. ${ }^{106}$ For Chief Justice Rehnquist, the answer has long been yes. ${ }^{107}$ There is the faintest (but to my mind frightening) suggestion

103. I have long believed that MacKinnon's question, while useful in framing the issue, is unlikely to lead to workable rules or standards that will allow an escape from a basic commitment in the direction of either sameness or difference, however. See, e.g., Case, Disaggregating Gender, supra note 4 , at I02 n.359 (using the example of surrogacy, as to which "some feminist theorists see subordination in commodification of the uniqueness of pregnancy (that is, see difference as non-subordinating) and others see subordination in a prohibition on women's right freely to contract to provide a service over which they have market power (that is, see sameness as nonsubordinating)" to illustrate this difficulty).

104. Discussed briefiy in text accompanying infra note 111.

105. See, e.g., Mary Anne Case, Of Richard Epstein and Other Radical Feminists, 18 HARv. J. L. \& PuB. Pol'y 369, 378-83 (1994); Case, supra note 3, at 1471 (arguing that much of the constitutionalizing of women's equality in current U.S. law is imtended as a repudiation of Justice Bradley's assertion in Bradwell v. Illinois, 83 U.S. (16 Wall.) 130, 141-42 (1872), that "'rules of civil society must be adapted to the general constitution of things, and cannot be based upon exceptional cases").

106. I have already set forth my own commitment to antidifferentiation as an appropriate end in itself, and iny conclusion that the answer to this question ought to be no, even in the unlikely event genuinely equal separate spheres for men and women were possible. See, e.g., Case, supra note 3, at 1472-77. See generally Case, supra note 58. I would not be inclined to have the United States follow the example of France, whose recent commitinent to "parity" may, I fear, be too direct a descendant of the French Revolutionary tendency to exclude ouly women when dissolving the three estates into an otherwise undifferentiated citizenry. See Mary Anne Case, "La Révolution N'a Rien Fait Pour Les Pauvres Femmes": The Rhetoric and Reality of Political Rights for Women in the French Revolution (unpublished manuscript, on file with the author). Even though I would be delighted to see more women in elective office, iny ultimate normative ideal is closer to the dissent in Marchioro v. Chaney, 582 P.2d 487 (Wash. 1978). Although the majority held that a requirement of French-style sexual "parity" for the State Democratic Committee was consistent with the goals of the Washington State ERA "to assure women actual as well as theoretical equality of rights," $i d$. at 491 , the dissent objected that by approving strict quotas by sex, "the majority opinion prevents the Equal Rights Amendment from achieving its purpose of making sex a neutral factor, one to be disregarded in favor of ability and performance." Id. at 497 (Horowitz, J., dissenting).

107. Rehnquist sets this answer out most eloquently in his Virginia concurrence. See U.S. v. Virginia, 518 U.S. 515, 565 (1995) (Rehnquist, C.J., concurring).

An adequate remedy in iny opinion might be a demonstration by Virginia that its interest in educating men in a single-sex environment is matched by its interest im educating woinen in a single-sex institution. To demonstrate such, the Commonwealth does not need to create two institutions with the same number of faculty Ph. D.'s, similar SAT scores, or comparable athletic fields. Nor would it necessarily require that the women's institution offer the same curriculum as the men's; one could be strong in computer science, the other could be strong 
that the Supreme Court majority in Nguyen may agree with Rehnquist. That opinion by Justice Kennedy upheld a differentiating statutory scheme ${ }^{108}$ with the explanation that " $[t]$ he distinction embodied in the statutory scheme... is not nnarked by misconception and prejudice, nor does it show disrespect for either class." 109 If this is all it now takes for a new majority of the Supreme Court to uphold sex-respecting rules (especially if that majority defines an absence of "misconception and prejudice" as deferentially as it did in Nguyen, whose unsuccessful plaintiff was a stereotype-beating nonmarital father who had raised a child abandoned by its mother), proponents of, for example, the new experiments in single-sex education can expect a newly warm reception from the Court. (I realize these are awfully few, awfully ambiguous words to pin this big a prediction on, but they are importantly different words in support of an even more importantly different result than any reached by our hero Ruth Bader Ginsburg.)

It is interesting that Sullivan chose as her title Constitutionalizing Women's Equality rather than Constitutionalizing the Equality of the Sexes. Even if one were only concerned about women (or, as Sullivan puts it, about class, not classification), ${ }^{110}$ one should, I think, conclude that it is not enough to get for women what men have. While, with respect to race, granting to "[a]ll persons ... the same right[s] ... as [are] enjoyed by white citizens" may be to grant non-Whites all the rights they need, giving women "the same right[s] ... as [are] enjoyed by [male] citizens" is in several respects not nearly enough. ${ }^{111}$

in liberal arts. It would be a sufficient remedy, I think, if the two institutions offered the same quality of education and were of the same overall caliber.

Id.

I08. Of course, as I have noted before, any statutory scheme involving pregnancy, as Ngzyen's does, almost necessarily implicates questions of equality in differentiation. See Case, supra note 3, at 1483.

If men and women are not quite similarly situated with respect to their children, at least at birth, how do you treat "unalikes" equally? An insistence that pregnancy is unique is no help here, since, that granted, the questions begin-some regime must be established for both mothers and fathers, and, unless pregnancy is to count for nothing (as it would in a scheme based simply on the fact of blood relationship), or to count for everything (with no father's rights at all), its uniqueness is question begging. What then should be set aside pregnancy in Id. establishing requirements for rights flowing from fatherhood?

109. Nguyen v. INS, 533 U.S. 53, 73 (2001).

110. By the way, contra Sullivan, the class of women may be neither insular, nor a minority, but it is about as discrete as any class known to the law, far more discrete than any racial class. The very structure of our language forces a division of all persons into exactly two discrete, nonoverlapping groups: "he"s and "she"s. Notwithstanding the efforts of activists for the transgendered and intersexed, the ubiquitous question, "Is it a boy or a girl?" rarely admits responses such as "both" or "neither." And Sullivan herself highlights the "irreducible biological difference between men and women that has no analogue for race." Sullivan, supra note 2, at 744.

111. 42 U.S.C. $\S 1981$ (1994). Or, to paraphrase the old feminist slogan, a woman who aspires only to the rights of man lacks ambition. 
First, so-called "real differences" between men and women may lead to men and women needing different things, as critics of the law's tendency to assimilate women to a male standard have long observed. In this context, it is worth noting that just as problematic as Sullivan's equation of rules-standards with specificity-generality is her conflation of classification-class with formal-substantive. With apparent approval, Sullivan cites the provision of "the Uganda[n] Constitution, which provides that "women shall be accorded full and equal dignity of the person with men."112 Such a provision could indeed be interpreted so as to provide "the class of women" with substantive equality. But generations of feminist theorists have long insisted that ineasuring what women are entitled to by what men have risks leading to the most arid of merely formal equality.

A second and less obvious difficulty with merely giving women the rights of men is that some of what men have chosen to grant to and value in themselves is frankly not so hot. Consider the Virginia Military Institute ("VMI") and its so-called adversative method. Educational experts called to testify at trial in United States $v$. Virginia claimed none of their number advocated the adversative method for either men or women. ${ }^{113}$ Yet, even Justice Ginsburg took the method's claimed virtues at face value and failed even to consider the possible advantages of the kinder, gentler VWIL approach for students of both sexes. "Kept away from the pressures, hazards, and psychological bonding characteristic of VMI's adversative training," she wrote, "VWIL students will not know the "feeling of tremendous accomplishment' commonly experienced by VMI's successful cadets." 114 The staggeringly widespread, ${ }^{115}$ although often unsupported, ${ }^{116}$ character of the assumption that what is associated with males must be good should perhaps lead to a more aggressive application of constitutional disparate impact law. Perhaps, for example, the Court should have been more receptive to a claim that the association of males with veteran status played an impermissible part in the preference that excluded Feeney and other women from high-echelon jobs in the Massachusetts civil service. ${ }^{117}$

112. Sullivan, supra note 2, at 751 (discussing the UGANDA CONST. art. 33 (1995)).

113. See Case, Two Cheers, supra note 92, at 363-64.

114. Virginia, 518 U.S. at 549 (citation omitted). For my own evaluation of the success of the two institutions' methods on the basis of lengthy observation of both VMI and VWIL, and for further discussion of what is at stake in the choice of masculine standards over feminine ones, see Case, Two Cheers, supra note 92.

115. See, e.g., Case, Disaggregating Gender, supra note 4, at 33 (reviewing cross-cultural evidence that shows that the "content of what is gendered masculine or feminine varies radically from culture to culture, but what remains constant is that whatever is gendered feminine is seen as less valuable than what is gendered masculine").

116. See, e.g., id. at 84-91 (presenting evidence that neither Sears nor the LAPD improved performance by using masculme hiring criteria); Case, Two Cheers, supra note 92, at 363-77 (same for educational and lawyering methods).

117. Pers. Adm'r. of Mass. v. Feeney, 442 U.S. 256, 269-70 (1979). So-called “women's requisitions" (of the lower echelon, clerical variety) were initially excluded by law from the veterans' 
A third difficulty with a focus on women alone, even if one's concern is only for women, is the tendency of men and women to live linked lives, something Ruth Bader Ginsburg highlighted in bringing so many of her pathbreaking cases, not so much on behalf of men, as on behalf of married couples. ${ }^{118}$ In many of her cases, husband and wife indeed had a shared fate and a common interest, so as to make it difficult to disentangle whose rights were at issue. For example, to deny survivor's benefits to widower Wiesenfeld would have discrimmated against both his deceased wife as wage earncr and him as surviving caregiver to their child. ${ }^{119}$ Unless we make space, in law and in life, not only for female wage earners and providcrs, but also for male homemakers and caregivers, we run the risk of constitutionalizing, not so much women's equality, as their availability for what Arlie Hochschild calls "the second shift."120 Equalizing women to men as a one-way ratchet runs that risk. Consider thc oft-quoted, eloquent rejection of sex-role stereotyping in Blackmun's Stanton v. Stanton majority opinion: "No longer is the female destined solely for the home and the rearing of the family, and only the male for the marketplace and the world of ideas." 121 Note the subtle lack of parallelism ("only the male", not "the male only"). Women are now welcome in both the public and private spheres, but what of men? "Women's activities and responsibilities are increasing and expanding," Blackmun continues. ${ }^{122}$ Indeed they are, but are men's to the same extent? ${ }^{123}$ Sullivan tends optimistically to imagine that the frequent economic interdependence of the sexes will cause men to support women's economic gains, and so it may in two-earner households. Unfortunately, neither economic interest nor what Sullivan calls "sympathy" has yet led most men to "support the aspirations of women they live with" for more help around the house. ${ }^{124}$

What has women's need for help with housework to do with constitutionalizing women's equality? To begin with, it may cast real doubt on the sustainability of both Sullivan's endorsement of "nornative pluralism" through "[c]onstitutional immunity for a private sphere" and her dichotomy

preference and, by the time of Feeney, were the sort of "lower paying positions for which males traditionally had not applied." Id. at $270 \&$ n.22.

118. For a discussion of two of these cases, see Sullivan, supra note 2, at text accompanying note 41. See also Case, Disaggregating Gender, supra note 4, at 10 \& n. 10.

119. Weinberger v. Wiesenfeld, 420 U.S. 636 (1975).

120. Arlie Russell Hochschild \& Anne Machung, The Second Shift: Working Parents AND THE REVOLUTION AT HOME (1989) (detailing the tendency of women in two-earner families to do the bulk of housework and child care).

121. Stanton v. Stanton, 421 U.S. 7, 14-15 (1975).

122. Id. at 15 .

123. To be fair, Blackmun may have thought men had always becn involved in "the hoine and the rearing of the family," but the fact remains that the classic separate spheres have been unevenly dissolvcd, with wounen's entry into spheres previously reserved for men far more frequent and encouraged than inen's into spheres generally reserved for women.

124. Sullivan, supra note 2, at 743. 
between "judicially enforceable standards" and "hortatory norms." 125 In my view, Sullivan overstates, even under existing constitutional law, the permissible or desirable scope for normative pluralism on matters concerning women's equality in the United States. ${ }^{126} \mathrm{We}$ as a nation are now constitutionally committed, not only to the equality of the sexes, but to the proposition that "fixed notions concerning the roles and abilities of males and females" 127 are problematic when enibodied in law. At least to this extent, we as a nation have a constitutional "consensus on the substance of equality." 128 Equality of the sexes is up there with racial equality as a fundamental constitutional commitnent our government must fulfill, even im its arguably hortatory pronouncements and necessary interventions into the private sphere. ${ }^{129}$ Thus, while government as speaker and dispenser of subsidies is free to take a variety of positions, ${ }^{130}$ among the positions it may now no longer take nor promote is, for example, that of Justice Bradley in Bradwell that, "[t]he natural and proper timidity and delicacy which belongs to the female sex evidently unfits it for many of the occupations of civil life [and so forth]." ${ }^{131}$ Moreover, government as decision maker must also act consistently with its commitunent to sex equality.

What might this mean im practice? Consider a few examples, some more hypothetical than others. First, at one extreme of the hortatory axis, what constitutional limits might there be on mere government pronouncements of principle unmoored from direct, binding connection to policy? In

125. Id. at 755,761 .

126. Cf. Roberts v. U.S. Jaycees, 468 U.S. 609,623 (1984) (holding a state's "compelling interest in eradicating discrimination against its fenale citizens justifies" restrictions on associational freedoms of ineinbers of a hitherto all-inale club forced by state law to stop discriminating on grounds of sex when admitting meinbers).

127. Miss. Univ. for Woinen v. Hogan, 458 U.S. 718, 725 (1982).

128. Sullivan, supra note 2 (earlier draft, on file with author).

129. The strength of our constitutional commitment to racial equality has led to constitutionally mandated limitations on government tolerance of and participation in private discriminatory acts. See, e.g., Shelley v. Kraemer, 334 U.S. 1 (1948) (placing constitutional limitations on court's ability to enforce racially restrictive covenant on private land); Griffin v. County Sch. Bd., 377 U.S. 218 (1964) (placing constitutional limitations on ability of county to close public schools and subsidize private ones rather than desegregate); Norwood v. Harrison, 413 U.S. 455 (1973) (placing constitutional limitations on state's ability to subsidize private racially discriminatory schools); Palmore v. Sidoti, 466 U.S. 429 (1984) (placing constitutional limitations on ability of court deciding child cnstody to take possibility of private racial prejudice against family into account). I need not go so far as to say that the result in each of these cases should have been the same if the private discrinination at issue had been instead on grounds of sex in order to insist that Sullivan's wholesale endorsement of "normative pluralism" on matters of sex equality goes way too far toward the opposite extreme.

130. The Court has famously said the U.S. government nay, for example, promote childbirth over abortion. See, e.g., Rust v. Sullivan, 500 U.S. I73 (1991).

13I. Bradwell v. Illinois, 83 U.S. (16 Wall.) I30, 141 (1872) (Bradley, J., concurring). For an argument similar to the one I make here, see Linda C. McClain, The Domain of Civic Virtue in a Good Society: Families, Schools and Sex Equality, 62 FordHAM L. Rev. 1617, 1637 (2001) (arguing that "federal constitutional norms have put limits upon government's ability to perpetuate traditional gender norms"). 
1993, the commissioners of Cobb County, Georgia, adopted resolutions proclaiming, inter alia, "that 'the traditional family structure' is in accord with community standards,... that 'lifestyles advocated by the gay community' are incompatible with those standards... and that Cobb County would not fund 'activities which seek to contravene these existing community standards." 132 If, by "traditional family structure," the commissioners had explicitly indicated that they meant, not just a heterosexual couple, but a patriarchal one, with wives submissive to husbands and confined to the domestic sphere as Justice Bradley urged, the resolution would violate existing U.S. constitutional equality norms. "[L]ifestyles advocated by the [feminist] community"133 can no longer be "incompatible with the" official community standards of any unit of government in the United States. "Welcome to Cobb County, Where a Woman's Place is in the Home" would be a combination of welcome mat and no-trespassing sign with, in my view, serious constitutional problems.

The problems only intensify when government seeks to use its powers to fund or regulate to promote such a problematic message. Attention to such problems is particularly urgent at times such as the present, when the federal government is becoming increasingly interested in sending messages about appropriate family structure and sexual behavior backed by carrots and sticks. For example, assuming arguendo that "promoting marriage" through subsidies, hortatory, and regulatory means is an appropriate activity for the federal government, it is still constitutionally constrained to promote only egalitarian marriage. ${ }^{134}$

Sex-equality norms also constrain government on those occasions when it necessarily adjudicates concerning the family. For example, government should no more select as appropriate adoptive parents those who believe and will teach their children that females are inferior to and ought to be subservient to males than it would those who believe non-Whites are

132. Joel Achenbach, A Report from the Front Line of the 'Culture War, ' WasH. Post, Sept. 26, 1993, at G1. The resolution was prompted by commissioners' objections to the subsidized production of Terrence McNally's Lips Together, Teeth Apart. 1t went unchallenged in court because it had no legal force-it was simply a declaration of principlc. See, e.g., Caroline Davies, The Man Who Dared to Say No; How a 'Silent Majority' Found a Voice in the Backlash Against Washington's Gay Lobby, MAIL ON Sunday, August 22, 1993, at 8.

133. Those "advocated by the gay community" have a more ambiguous status under current law: So long as they do not transgress the limits set by the Court in Romer v. Evans, 517 U.S. 620 (1996), units of government still have some degree of freedom in the extent to which they celebrate or condemn "gay lifestyles." It should go without saying that, in adapting the language of the Cobb County resolution to my rhetorical purposes, I do not mean to suggest that this language is anything but hopelessly vague.

134. See, e.g., Linda McClain, Some Thoughts on Marriage (E)quality and Promoting a "Marriage Culture," (unpublished manuscript, on file with author) (describing and critiquing from a sex-equality standpoint the efforts to involve government in promoting marriage undertaken by, inter alia, Wade Horn, Assistant Director for Children and Families in the George W. Bush Administration's Department of Health and Human Services). 
inferior to and should be subservient to Whites. ${ }^{135}$ Should a strong commitment to traditional fixed sex roles doom a prospective adoptive parent? And to what extent should government as adjudicator of custody between already-recognized parents take commitment or opposition to women's equality into account? Must government disfavor im competition for children those who, for example, would make a girl do all the household chores while her brother goes out to play? ${ }^{136}$ Can it enter a support order providing funds, explicitly on grounds of sex, ${ }^{137}$ for a son's higher education but not a daughter's? ${ }^{138}$ These are more controversial questions, but, im confining her analysis of governmental immunity for normative pluralism in the private sphere to adult women's choices, ${ }^{139}$ rather than attending as well to the choices imposed on "young women," the divide between private and state action. Implicated as well are limits on the messages state-sponsored schools can offer: today such schools are not merely permitted ${ }^{141}$ but also required to refrain from promoting a message of inequality between men and women.

There are similar limitations on the government as employer, even of military personnel. Consider in this regard the recently brought case of McSally v. Rumsfeld, ${ }^{142}$ in which a female U.S. Air Force fighter pilot challenged regulations requiring female U.S. military personnel to be accompanied by a male companion and to wear an abaya on any trips off base im

135. I was first moved to reflect on these potential constitutional sex-equality constraints on adoption and custody as a result of a question Vicki Been asked at Rachel Moran's NYU Law School workshop presentation of chapters from her book INTERRACIAL. INTIMACY: THE REGULATION OF RACE AND ROMANCE (2001).

136. Would government ever think to allow adoption of a Black child as, in effect, a household servant for his or her White adoptive siblings? This, notwithstanding historical examples of poor children being adopted largely to provide an extra pair of hands for labor.

137. As opposed to differences in the individual academic abilities or interests of the siblings.

138. Stanton v. Stanton, 421 U.S. 7 (1975), dealt only with categorical state law, not individual parental decisions directly supervised or adjudicated by the state. But see id. at 19-20 (Rehnquist, J., dissenting) (suggesting that what was really at issue was a private agreement between the divorcing Stantons).

139. See Sullivan, supra note 2, at 755 n.125.

140. Id.

141. See Davis v. Page, 385 F. Supp. 395 (D.N.H. 1974) (upholding, against parents' free exercise objection, a school board's refusal to excuse young children froin classes presenting an untraditional view of sex roles). Although the New Hampshire District Court did not rely on constitutional sexequality guarantees, among the parents' rejected objections to the school curriculum were these:

Our schools are contributing to the Womans' [sic] Liberation Movement by making [it] mandatory that the boys take home economics and the girls take shop.... [B]oys between [the] ages of 12 and $16 \ldots$ are very vulnerable to effeminate or hoinosexual development if [a] certain environment is provided.... [] f] students who already have possible unknown problems in this area were placed in this atmosphere condoned and imposed by those in authority it would certainly contribute to a particular students [sic] overall destruction of masculinity. Men are the head of the family not the homemakers.... [W] insist that because our daughter is a girl she will just have to be treated like a girl and regardless of who else is taking home economics she will be taking it as well. our [sic] boy will take shop.

Id. at 402-04.

142. McSally v. Ruinsfeld, No. 1,01CVO2481 (D.D.C. 2001). 
Saudi Arabia. ${ }^{143} \mathrm{McSally}$ claimed that these regulations violated her constitutional rights, inter alia, "by forcing her to communicate the false and coerced message that she adheres to the belief that women are subservient to men, by according her different treatment and status based solely upon her gender, and by undermining her authority as an officer." 144 Just as there are constitutional limits on the U.S. government's deference to private discrimination of its citizenry, there ought to be limits to its voluntary deference to the "normative pluralism" of its allies on matters of sex and gender.

Messages of subordination that are largely symbolic but have real world effects extend well beyond the U.S. military in Saudi Arabia, however. Consider, as one perhaps controversial example, the recent decision by Vermont to reserve civil marriage for male-female couples and to offer same-sex couples a similar paekage of legal benefits if they enter into a new status, denominated civil union. This bifurcation, $m$ my view, sends a message of subordination to both gays and lesbians on the one hand and heterosexual women on the other, while reaffirming patriarchy. Although Vermont is to be commended for extending as many rights as it has to same-sex couples, ${ }^{145}$ by withholding from them the opportunity to marry, it devalues their unions both practically and symbolically. And, by restricting marriage to male-female couples and male-female couples to marriage, it forces women who wish to unite with men under state law to do so $\mathrm{m}$ an institution whose all too recent legal history is of subordinating wives both practically and symbolically, an institution Vermont is reserving for them alone because of and not in spite of its "traditional" (that is, patriarchal) significance. While civil union may have gone a long way toward constitutionalizing the equality of gay men and lesbians in Vermont, it was, in my view, a step backward for constitutionalizing the equality of straight women. ${ }^{146}$

143. An abaya is a full-length enveloping dark robe worn by women in the Gulf States to comply with traditional Islamic requirements of "hijab" or modest covering of wounen's bodies.

144. Plaintiff's Coinplaint at para. 11, McSally (No. 1,01CVO2481). I am grateful to iny colleague Adrian Vermeule for providing a copy of the complaint and for so vehemently expressing his own indignation at McSally's treatınent.

145. More than any other state to date.

146. Note that, if Vermont opened either marriage to same-sex couples or civil union to inalefemale couples, I would not be complaining about an affront to women's equality. For, if marriage were opened to all couples, it could continue its development away from its patriarchal past rather than be preserved in the tradition of that past. And, if civil union were open to all couples, women who wished to receive state recognition of their union with a man, together with the associated bundle of legal benefits, could do so without being forced to submit to entry into a form of union that traditionally has subordinated them. For further discussion, see Mary Anne Case, What Stake Do Straight Women Have in the Same-Sex Marriage/Civil Union/Domestic Partnership Debates? (unpublished manuscript, on file with author) (presented at the 2002 Annual Meeting of the Association for Law, Culture, and the Humanities). 
In some ways marriage is like an abaya: ${ }^{147}$ Some women who voluntarily enter the one or put on the other do so without feeling or imtending to "communicate ... a belief that women are subservient to men." 148 Others by such acts embrace and announce their adherence to such a belief, as is their personal right. But a government committed to constitutionalizing women's equality in the way that U.S. law now demands should not condition important privileges, mcluding membership in the armed forces and in a legally recognized union, on a woman's willingness to accept trappings whose social meaning she reasonably associates with a message of subordination she (and this nation) rejects.

Because the first installment of this year's Jorde Symposium was held on the evening before oral argument in the first of the Florida election cases to reach the Supreme Court, ${ }^{149} \mathrm{I}$ found it impossible not to draw parallels to that battle. The advice all too often given Al Gore, advice he finally took a month after that oral argument, is familiar to many of the women I study. Like $\mathrm{Al}$ Gore, rape victims, divorcing spouses facing battles over custody and assets, victims of sexual harassment who can choose to file a grievance or grin and bear it, women who lose one job because of employment discrimination but can readily find another, all are often told: "Don't go to court. Don't assert your claims. For the sake of your own dignity and peace of mind, for the sake of broader peace, put it all behind you and move on." Unfortunately, this may be perfectly correct advice when only the self-imterest of the injured party is at issue. It may also be the most comfortable advice for observers fearful of getting caught in the crossfire. But, from the perspective of justice and the rule of law, it may not be the best advice.

In his concession speech, Gore made reference to the motto einblazoned over the facade of the Harvard Law School: ${ }^{150}$ "Not under man, but under God and law."151 Above another great law school, the University of Michigan, alma mater of Martha Griffiths, ${ }^{152}$ is inscribed a less comfortable motto: Fiat justitia, mat coelum. ("Let justice be done, though the heavens

147. Among other similarities, they both historically involve the "covering" of women in circumstances where men are not similarly covered: an abaya physically through its cumbersome enveloping folds; marriage legally, through the encumbrance of coverture, which subsumed a wife's identity in her husband's. See Sullivan, supra note 2, at 736 n.10.

148. Plaintiff's Complaint at para. I I, McSally (No. 1,01CVO2481).

149. An oral argument for which Sullivan departed the symposium to sit at counsel table for respondent Gore.

150. The alma mater sbared by four of the five participants in this year's Jorde Symposium, as well as a majority of the Justices now on the Supreme Court.

151. Although this was the English translation cited by Gore himself, and although it has an interesting resonance in the context of this symposium, the actual Latin motto is less sexrespecting: Non sub homine (human being), sed sub deo et lege.

152. See Commission on the Bicentenary of the U.S. House of Representatives, Office of the Historian, Women in Congress rgr7-r9go (1991). 
fall.") ${ }^{153}$ Understandably, few of us, Al Gore included, are willing to bring the heavens down around us in our quest for justice. ${ }^{154}$ But it is important to remember that no constitutional guarantees, whether those of women's equality or of free and fair elections, are safe or are worth much unless we are prepared to fight for them and to support others in their fight, even past the point where it is comfortable to do so.

153. I am grateful to Lisa Dresner of the University of Michigan library for confirming in a telephone conversation that this inotto was indeed on the north door from Hutchins into the Law Quad.

154. I understand perfectly well why Gore conceded when he did. I also understand why so many victims of doinestic violence are willing to drop the charges, why women threatened with a custody fight may respond by yielding financial claims to which they are entitled, why so few rape victims come forward, and so on. 